\title{
Guide Structures in CD-ROM Dic- tionaries, with Specific Reference to the EWED and the ELHAT
}

\author{
Phillip Louw, Bureau of the Woordeboek van die Afrikaanse Taal, Stellen- \\ bosch, Republic of South Africa
}

\begin{abstract}
Much of the success of modern dictionaries depends on the accessibility of their macro- and microstructural information. In order to evaluate the methods which lexicographers employ to improve dictionary accessibility, the concept of guide structures was introduced by Hausmann and Wiegand (1989). Since the appearance of that article, various academics have written articles and read papers on guide structures in print dictionaries, but few studies have focussed on the tremendous potential of guide structures in electronic dictionaries.

In this article it will be shown that electronic dictionaries add dimensions to the implementation of guide structures not possible in print versions. The role of two of the guide structures in the transfer of information in CD-ROM dictionaries will be discussed. The access and mediostructures of the Microsoft Encarta World English Dictionary and the Elektroniese Handwoordeboek van die Afrikaanse Taal will be analysed and critically evaluated to illustrate the advantages of electronic dictionaries over print dictionaries and the urgent need for metalexicographical discussion of this publication medium.
\end{abstract}

Keywords: ACCESS STRUCTURE, ACTIVE CROSS-REFERENCES, CD-ROM DICTIONARY, DICTIONARY ACCESSIBILITY, ENCYCLOPAEDIC DICTIONARY, GUIDE STRUCTURES; INNER ACCESS STRUCTURE, INNER SEARCH PATH, INTERNET, MEDIOSTRUCTURE, MULTIMEDIA, OUTER ACCESS STRUCTURE, OUTER SEARCH PATH, PASSIVE CROSSREFERENCING, USER-FRIENDLINESS

\section{Opsomming: Gidsstrukture in CD-ROM-woordeboeke, met spesifieke ver-} wysing na EWED en ELHAT. Die sukses van moderne woordeboeke hang grootliks af van die toeganklikheid van hulle makro- en mikrostrukturele inligting. Hausmann en Wiegand (1989) het die konsep van gidsstrukture ingevoer om die metodes te evalueer wat leksikograwe gebruik om woordeboektoeganklikheid te verbeter. Sedert hierdie artikel verskyn het, het verskeie akademici artikels gepubliseer en referate gelewer oor gidsstrukture in gedrukte woordeboeke, maar min studies het gefokus op die geweldige potensiaal van gidsstrukture in elektroniese woordeboeke.

In hierdie artikel sal dit getoon word dat elektroniese woordeboeke geleenthede vir die implementering van gidsstrukture skep wat nie in gedrukte weergawes moontlik is nie. Twee'van die gidsstrukture se rol in die oordrag van inligting in CD-ROM-woordeboeke sal bespreek word. Die toegang- en mediostrukture van die Microsoft Encarta World English Dictionary en die Elektroniese Handwoordeboek van die Afrikaanse Taal sal ontleed en krities geanaliseer word, om die voordele 
van elektroniese bo gedrukte woordeboeke en die dringende behoefté aan die metaleksikografiese bespreking van hierdie publikasiemedium te illustreer.

Sleutelwoorde: AKTIEWE KRUISVERWYSINGS, CD-ROM-ENSIKLOPEDIE, EKSTERNE SOEKROETE, EKSTERNE TOEGANGSTRUKTUUR, ENSIKLOPEDIESE WOORDEBOEK, GEBRUIKERSVRIENDELIKHEID, GIDSSTRUKTURE, INTERNE SOEKROETE, INTERNE TOEGANGSTRUKTUUR, INTERNET, MEDIOSTRUKTUUR, MULTIMEDIA, PASSIEWE KRUISVERWYSINGS, TOEGANGSTRUKTUUR, WOORDEBOEKTOEGANKLIKHEID.

\section{Introduction}

To many dictionary users the consultation of dictionaries - even reputable ones - can often be a labyrinthine affair. In order to evaluate the methods which lexicographers employ to lead the users through these labyrinths, the concept of guide structures was introduced by Hausmann and Wiegand (1989). This subset of structures is a key element of the structural theory, which, in turn, is a central part of Wiegand's textual theory for lexicographic texts. Since the appearance of that article, various academics have written articles and read papers on guide structures in print dictionaries, but few studies have focussed on the tremendous potential of guide structures in electronic dictionaries. However, Louw (1999a) has shown that the theory of guide structures can be applied without much difficulty to the study of electronic dictionaries. In fact, electronic dictionaries add dimensions to the implementation of guide structures not possible in print versions.

Two of the roles of the guide structures in the transfer of information in CD-ROM dictionaries will be discussed. The access and mediostructures of the Microsoft Encarta World English Dictionary (henceforth EWED) and the Elektroniese Handwoordeboek van die Afrikanse Taal (henceforth ELHAT) will be analysed and critically evaluated to illustrate the advantages electronic dictionaries hold over print dictionaries and the urgent need for metalexicographical discussion of this publication medium.

\section{Access structures in electronic dictionaries}

Louw (1999: 109) describes the access structure as "the primary guide structure". It is through the use of the access structure of any dictionary that the necessary information is found. The macro- and microstructural content of a dictionary may be adequate or even excellent, but without an adequate access structure the user may very well be frustrated in his/her search. Gouws and Prinsloo (1998: 18) affirm this point: "One of the most important characteristics of a good dictionary is its accessibility. Accessibility leads to an unambiguous retrieval of the information presented on both the macro- and microstructural levels." 
Louw (1999: 109) adds: "The access structure is, however, not a singular entity: It encompasses certain substructures, of which the outer and inner access structures are the most important." In the dictionaries under discussion, there is innovation in both the outer and inner access structures.

\subsection{The outer access structure}

\subsubsection{The outer search path}

In electronic dictionaries, as in print dictionaries, the user follows an outer search path which takes him/her to the desired article and is aided on this search path by the outer access structure. The outer access structure can be divided into a rapid outer access structure and a standard outer access structure.

\subsubsection{The rapid and standard outer access structures}

In print dictionaries, the rapid outer access structure usually consists of elements such as indexes, thumb indexes, running heads and any features which bring the user rapidly to the vicinity of the article in which the relevant information is presented. Louw (1999: 111), however, states: "It cannot guide the user along the last, most vital part of the outer search path. The final choice of the desired macrostructural element is made by means of the standard outer access structure." Most print dictionaries are monoaccessible, i.e. the standard outer access structure corresponds to the macrostructure. This standard outer access structure encompasses decisions made by the lexicographer on, for example, an initial alphabetical or a thematic listing of lemmata, as well as the consistent implementation of these decisions.

In electronic dictionaries, it is not always easy to recognise the boundaries between the rapid and standard outer access structure. In the ELHAT there is a traditional presentation similar to that of the print version of this dictionary, but also some innovative hybrid elements. In the EWED innovative methods are employed throughout, combining elements of the rapid and standard outer access structures into single items or texts.

\subsubsection{ELHAT}

At first glance, the ELHAT seems to provide a conventional outer search path. The opening "browse" screen provides several elements of the rapid outer access structure (see Fig. 1). 


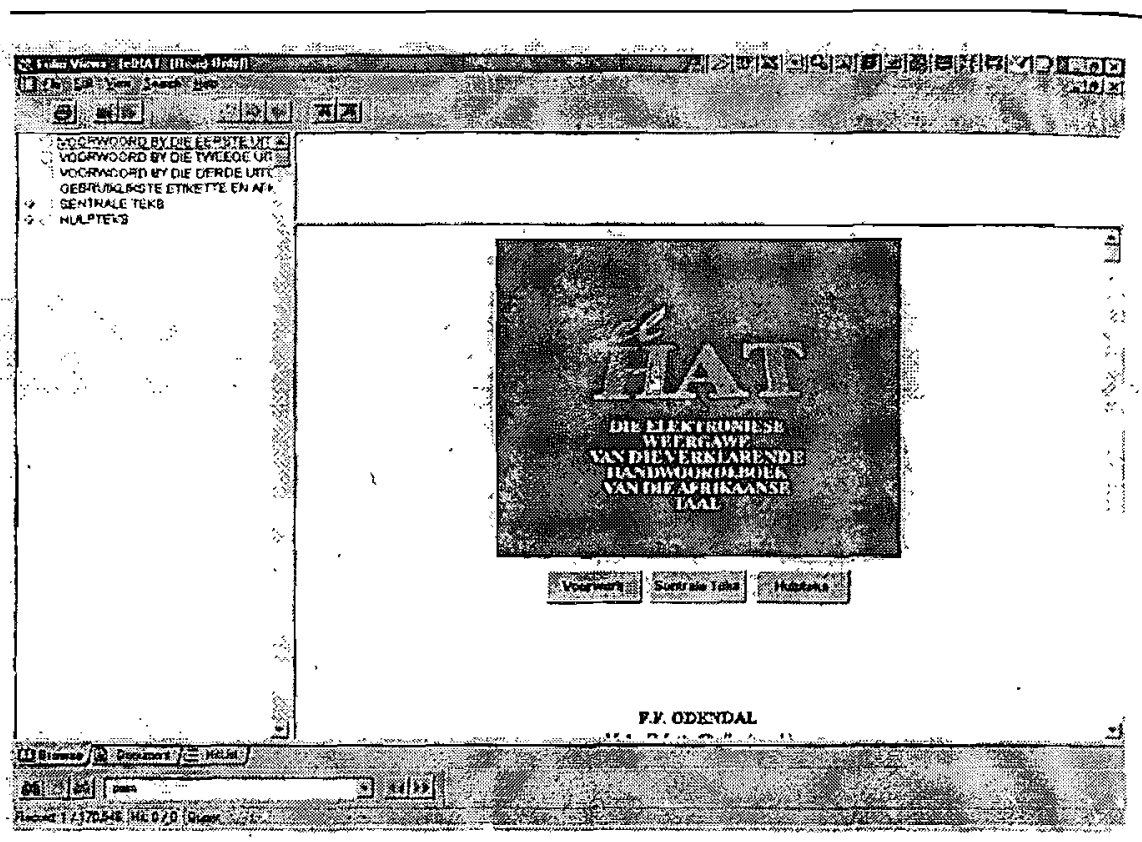

Fig. 1

An outline is given in a window on the left side of the screen. This outline provides active cross-references to transport the user to texts of the print version's front matter, the central text or an additional help text or user's guide which deals specifically with the structure, search patterns, etc. of the electronic version. The outline can provide rapid access to the macrostructure and therefore forms part of the rapid outer access structure. It shares this function with a button marked "Sentrale Teks" in the main window. A click here or in the outline will take the user to the central text, which is presented in scrollable format in the main window (the central text can be accessed separately by clicking on the icon entitled "Document" at the bottom of the screen).

At this point other elements of the rapid outer access structure take over. As a first step, the user can click on any of the 26 buttons representing the letters of the alphabet and will then be transported to the first lemma starting with that particular letter. From there the user can follow the standard outer search path by scrolling down to the lemma he/she is looking for. In order to maintain the "user addressing" (Louw and Gouws 1996: 98) of the print version, which is aimed at a very broad spectrum of Afrikaans speakers, the initial standard alphabetical outer access structure of the print version is retained unchanged. The elements of the rapid outer access structure which usually guide the user when turning the pages - the running heads - are, however, replaced. In the top right a small window shows which letter is currently consulted and displays the lemma sign of the article where the cursor is situated. This assists the user when he/she is scrolling rapidly through the central text. 
Thus far, all the elements have been fairly conventional and aimed at offering the user a look-up experience very similar to what he/she would experience when consulting the print version. The ELHAT does provide alternative search patterns, though. The initial alphabetical standard outer access structure can also be searched by using the customised "Soekwoorde"-window (see Fig. 2), which can be called up from the "search"-menu.

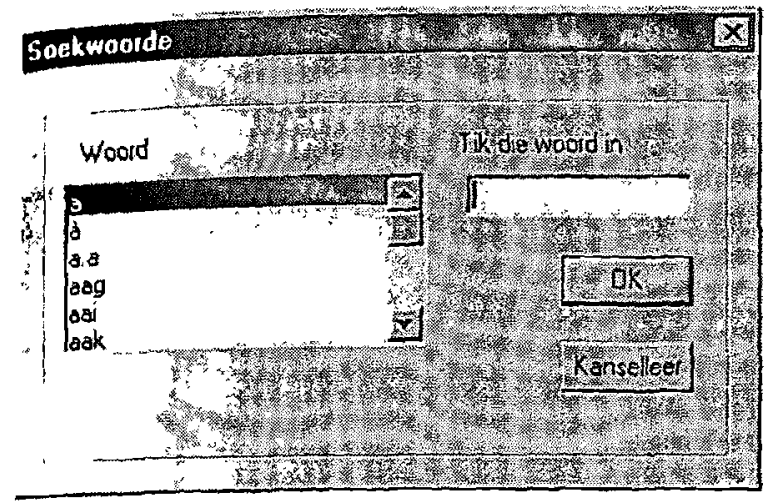

Fig. 2

A search using this tool bypasses conventional methods of searching and collapses the rapid and standard outer access structures into one by providing rapid access not only to the macrostructure, but also to the desired article.

A further innovation is the "Soekvelde"-window which presents an alternative to the conventional initial alphabetical standard outer access structure. A few simple procedures divide the macrostructure into thematic groups of lemmas (see Fig. 3).

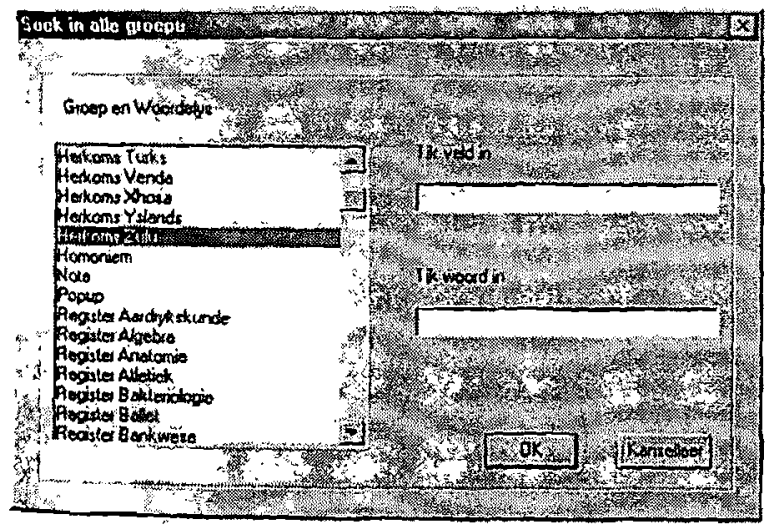

Fig. 3 
By selecting a field and then clicking in the "Tik woord in"-input box, a hit list appears in the "Groep en Woordelys"-display window (see Fig. 4).

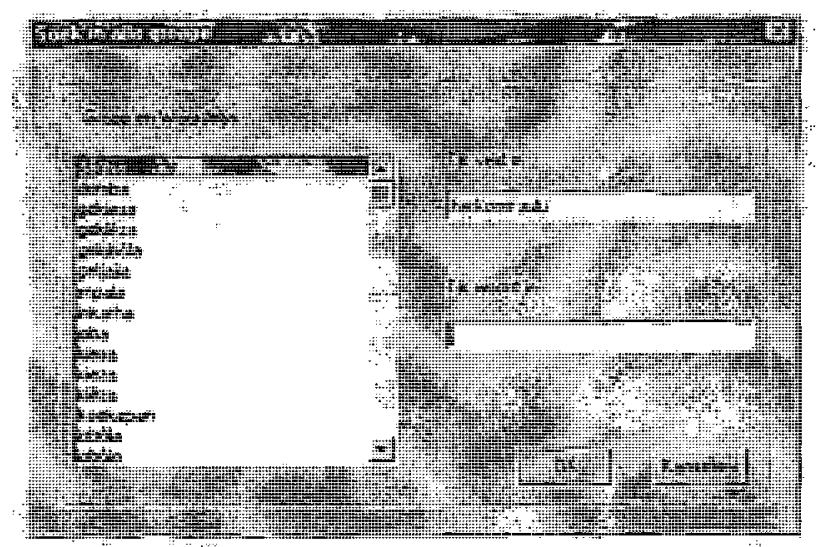

Fig. 4

Each group of lemmas represents a hit list, which can be searched by scrolling through them or by refining the search by typing in a search word. A click on "OK" will then take the user to the correct article.

\subsubsection{EWED}

The EWED-CD-ROM includes a thesaurus, a dictionary of quotations, a general monolingual dictionary and two bidirectional bilingual dictionaries. By choosing "everything" on the opening screen, searches can be conducted throughout all these dictionaries. For the purposes of this article, however, the procedures following the choice of "dictionary" on the opening screen will be focussed on. This link takes the user to the outer access structures of a general monolingual dictionary.

The outer access structure differs significantly from that of ELHAT. On the main window of both dictionaries, links are provided to various parts of the front matter, but whereas ELHAT has a link to the central text and search boxes available from menu items, EWED has a search aid that is always on the left side of the screen. This "pinpointer" is a trademark feature of the Encarta family. In the previous version of the Encarta Encyclopedia it acted as a "floating help text" (Louw 1999a: 288), but in both the Encarta Encyclopedia 2000 and EWED it is in a fixed position, which makes it easier for the target user to access.

As was the case with the search boxes in ELHAT, elements of the rapid and standard outer access structures are combined very effectively in EWED. The "pinpointer" lists the macrostructural items strictly alphabetically and scrolling down to the relevant lemma and clicking on it can access these (see 
Fig. 5). The main window then displays the selected article. In this procedure the "pinpointer" forms part of the standard outer access structure and has an important function. In cases where someone is unsure of the spelling of a lemma, it affords him/her the opportunity to find the desired lemma in a search procedure that he/she would be familiar with in a print dictionary.

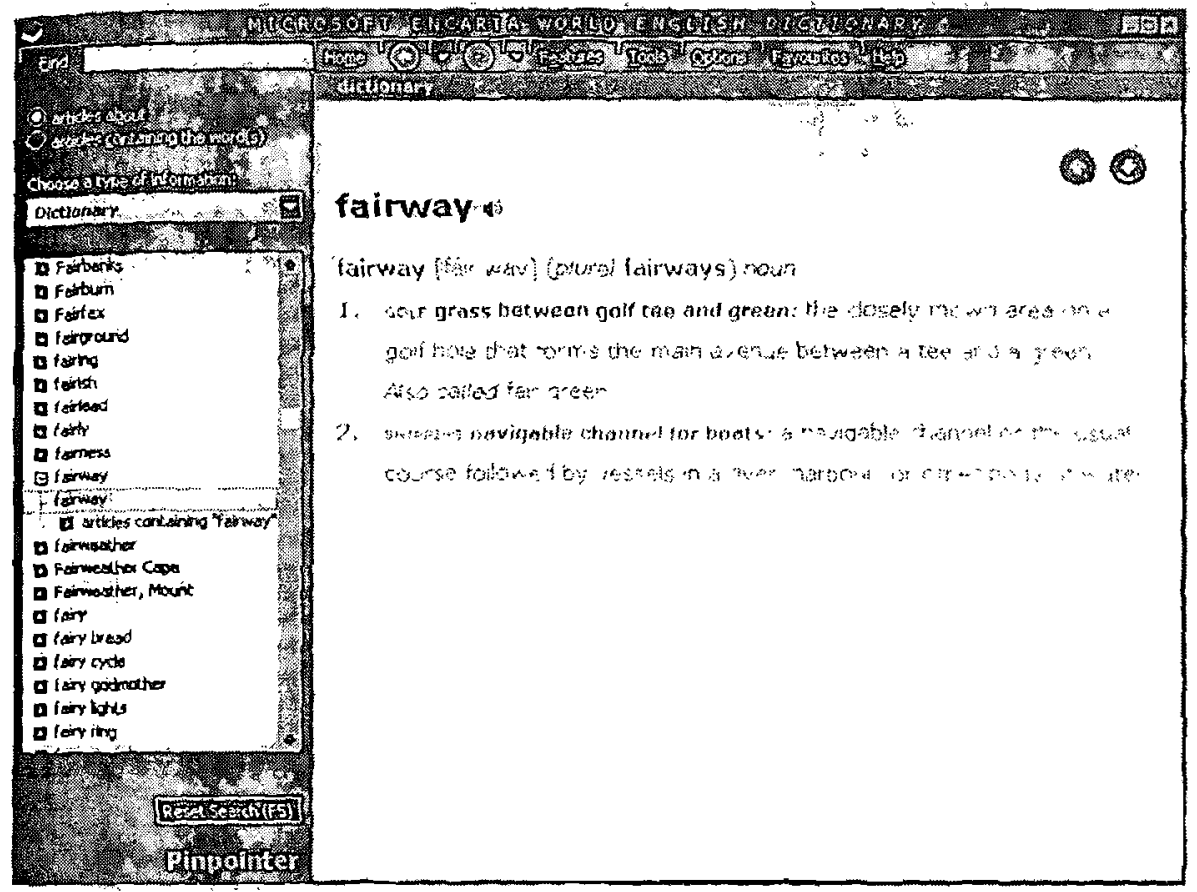

Fig. 5

This appreciation of familiarity is an important part of the user-friendliness of EWED. Louw's (1999a: 289) evaluation of the "pinpointer's" role in the Encarta Encyclopedia is therefore also valid here: "It is the preference for an initial alphabetic listing as the first step in searches using the 'pinpointer', that proves this commitment to the needs of target users, as an alphabetical listing would probably be preferred by families within the current dictionary culture".

Yet the "pinpointer" also functions as an element of the rapid outer access structure. Once the radio button labelled "Articles about" is activated a search word or phrase can be entered into the "Find" input box. The macrostructure of the dictionary is immediately scanned and the results are narrowed down as each letter is typed in. The relevant lemma is highlighted in the main display box of the "pinpointer". From here the article can be accessed directly and swiftly by a click, or the user can choose to follow a different, integrated search path. 


\subsection{An integrated approach to searches on the outer and inner search paths}

Not all the search options in CD-ROM dictionaries necessarily maintain the boundaries of the outer and inner access structure. Whereas passive structural markers and other search aids in print dictionaries are as a rule restricted in their application to either the outer or inner access structure, active markers and search functions in electronic dictionaries can follow an integrated approach to searches on the outer and inner search paths.

\subsubsection{EWED}

Both dictionaries offer advanced search functions. In the EWED there is a tadio button option to select all the "articles containing the word(s)". The entry of a search term provides a selection of relevant articles in which the search term can be found. This selection is displayed in the main list box of the "pinpointer", and the user can either scroll down or click on the desired article. His or her choice will then be displayed in the main window with the relevant term highlighted, be it a word, sublexical lexical item, multilexical lexical item, phrase or name.

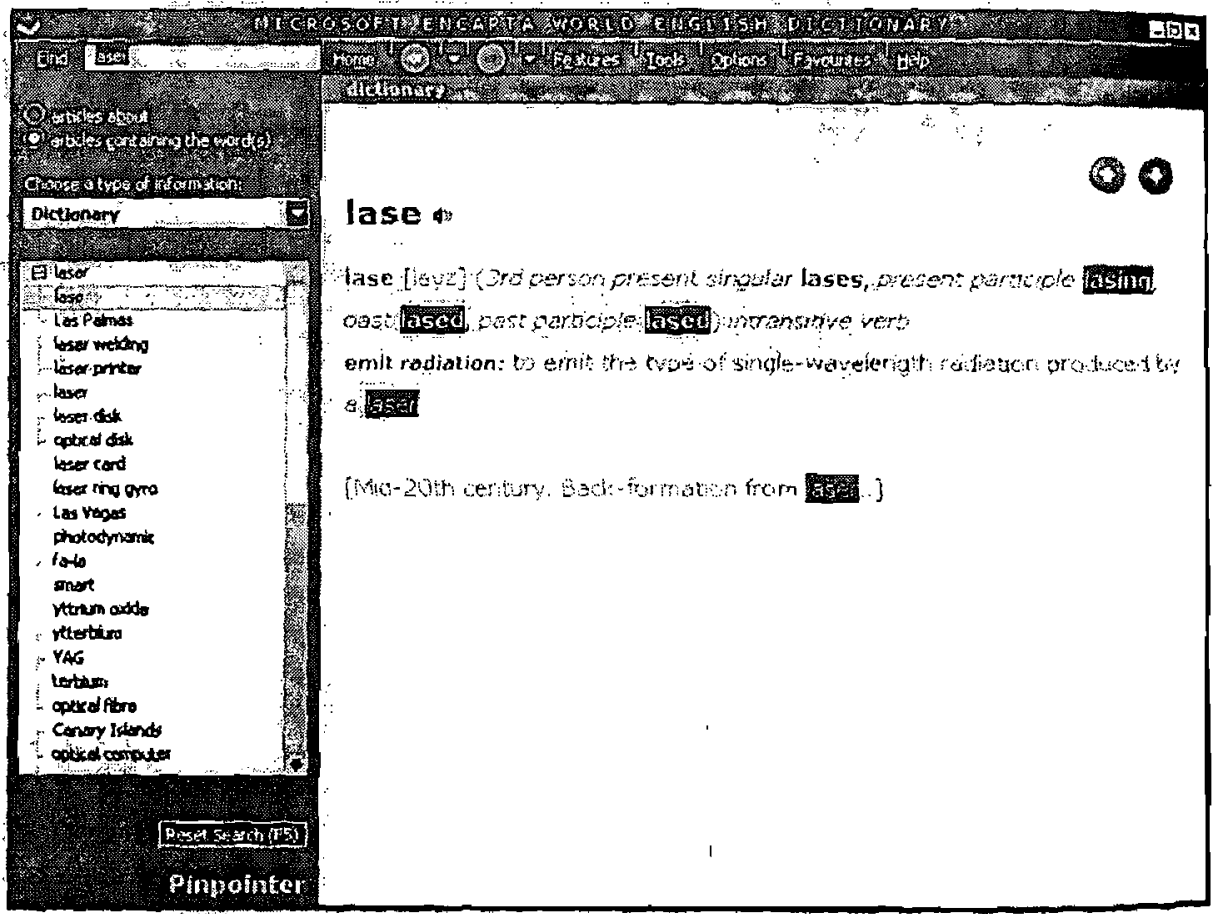

Fig. 6 
This search function is especially useful if the user needs more detailed information about a search term than is contained in the article with that term as lemma, if the user needs to know if a term not lemmatised as part of the macrostructure exists, or if the user is eager to learn about the semantic relations between the search term and other lexical items. The procedure is, however, not always applied consistently enough to be of full value to the user. If one searches for "laser", for example, the first lemma on the list is lase.

In this article all derivatives of lase are highlighted in the microstructure, whereas the user searched for "laser" (see Fig. 6). The user must therefore wade through useless information to reach the requested item. The situation is even less desirable in the next article, that for Las Palmas. The search term "laser" is not even present, with "Las" being highlighted. This degree of inaccuracy in searches frustrates the user and should be addressed in future editions of the EWED.

\subsubsection{ELHAT}

The ELHAT is far more advanced in this type of procedure. It provides two valuable query options. The first is a basic query that is similar to that of the EWED. A query-form can be selected from the search menu option and a search term entered (see Fig. 7).

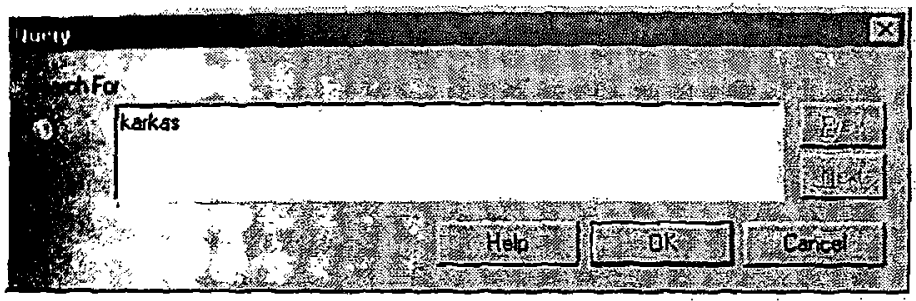

Fig. 7

The results will be compiled in a hit list, which can be accessed by clicking on the "HitList"-icon at the bottom of the main window. See for example the hit list for karkas (Fig. 8).

The hits can be selected individually and viewed in the document section by double-clicking on the selected item.

There is also a more advanced query procedure that illustrates the attention to the needs of the target users of the dictionary. The compilers of the dictionary knew that the target users frequently employ the dictionary as an aid in crossword puzzles. Rather than dismissing this need as unacademic, they have chosen to accommodate the users by making a "wild card"-search available. The "Advanced Query"-form can be accessed from the "Search"-menu item and is easy to use (see Fig. 9). 
The question mark was chosen as a structural marker in the search term to denote which letters of the term are not known. It is a good choice, as most users are familiar with this marker and what it denotes. The entry of a search term will lead to a selection of articles in the "Word"-list box and a corresponding selection in the hit list which can be accessed in the same way as that of the normal query.

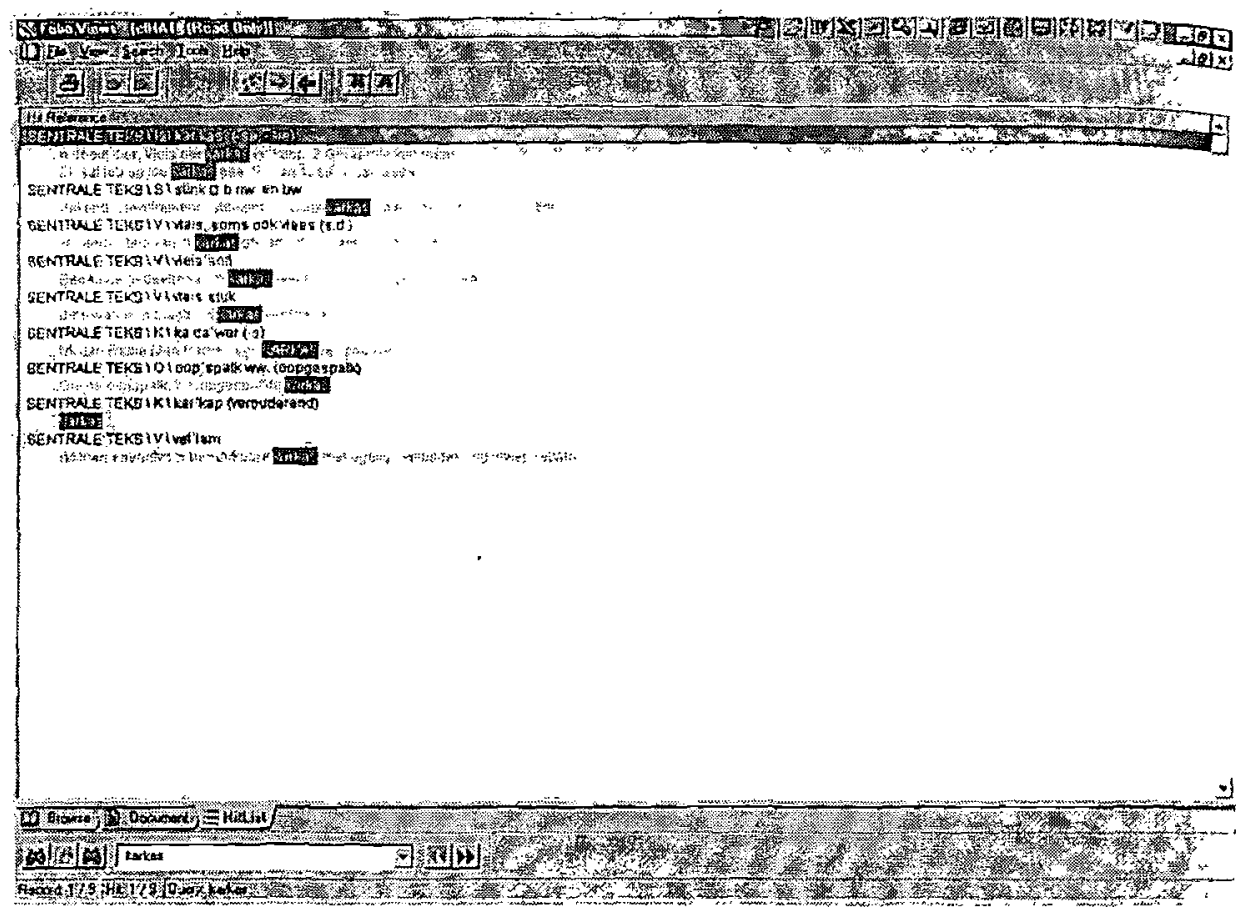

Fig. 8

\subsection{The inner access structure}

\subsubsection{The inner search path}

Most of the innovations in the CD-ROM dictionaries guide the user on the outer search path. As was shown in 2.2, however, there are some innovative search procedures that stretch to the inner search path. There are also some elements of the inner access structure which are unique to electronic dictionaries.

These unique elements will be discussed in this section. Elements of the inner access structure which are truly innovative in EWED, but are also included in the print version of this dictionary, will therefore not be discussed. 
Some care has been taken in EWED to enhance the "findability" of microstructural information. Unfortunately, the same cannot be said for ELHAT.

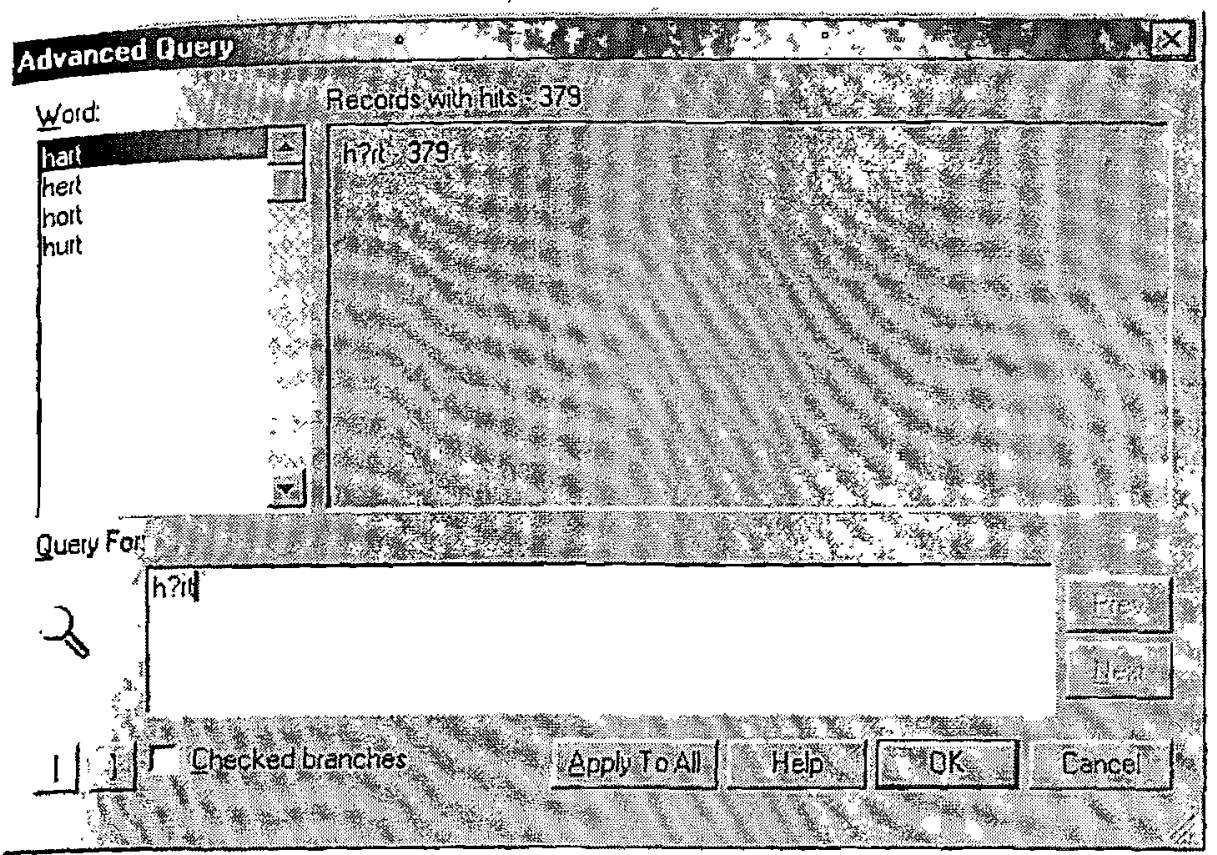

Fig. 9

\subsubsection{ELHAT}

ELHAT is in essence purely an electronic adaptation of a print dictionary, which has been on the market a long time and has not undergone major structural changes. This lack of structural innovation is reflected in the lack of elements of the inner access structure.

\subsubsection{EWED}

In the EWED, on the other hand, the use of multimedia has necessitated a fresh approach to the inner access structure. The first and most important multimedia element in EWED is the aid in pronunciation. There is an icon denoting a speaker next to some lemmas, which, if clicked on, provides the pronunciation in the form of a sound clip. The user is therefore granted rapid access to an accurate pronunciation. The icon denoting the speaker acts as a structural marker that forms part of the rapid inner access structure. 
The EWED can be classified as an encyclopaedic dictionary that breaks with the traditional distinction between encyclopaedia and linguistic dictionary, opting for a hybrid format. On a macrostructural level this has, for example, led to the inclusion of place names, etc. On a microstructural level it has not only had implications for the level of encyclopaedic information contained in the items giving the meaning paraphrases, but also owing to the inclusion of multimedia items that supports the transfer of encyclopaedic information. These include maps, diagrams, pictures (mostly photographs) and sound clips (such as the anthems of countries whose names have been lemmatised). The visual items are usually included as inserted inner texts, but in many cases these small items act as active cross-references which provide rapid access to enlarged versions of the inserted inner texts. The sound clips are introduced by means of an abstract icon. In all these cases the items act not only as cross-references, but also as effective, unique structural markers of the inner access structure, which introduce the multimedia.

\section{The mediostructure}

CD-ROM dictionaries have not only broken new ground with the inner and outer access structures. Some of the most telling innovations are to be found in their mediostructure, which encompasses all lexicographic cross-references in a dictionary.

\subsection{EWED}

As was shown in 2.3.2, active cross-references have a significant role in the successful use of multimedia, where smaller versions and abstract icons are used as links to separate audio and visual elements. In the case of visual elements such as maps or pictures, these links invariably lead to an illustration, which operates as a text that does not form part of the central text. The cross-references in this case are therefore text-external cross-references.

Active text-external cross-references are employed to great effect elsewhere in EWED. The active link to audio clips giving the pronunciation was discussed in 2.3.2, but these are not the only innovations in the pronunciation information. Whereas only some lemmas have audio clips, transcriptions are provided for almost all lemmas. These transcriptions have a green font colour, which shows that they are active text-external cross-references. A click on the pronunciation takes the user to a pronunciation guide, which can also be accessed separately as part of the front matter (see Fig. 10).

These cross-references offer instant help to the user who struggles with the pronunciation of a specific lemma. They improve the user-friendliness of EWED considerably and should be adopted by other CD-ROM dictionaries. 


\section{Pronunciation Key}

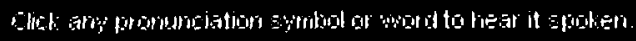

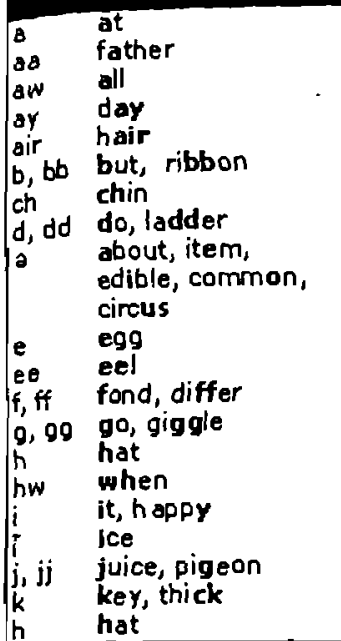

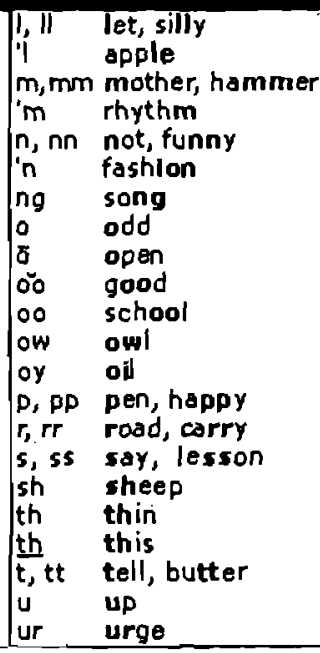

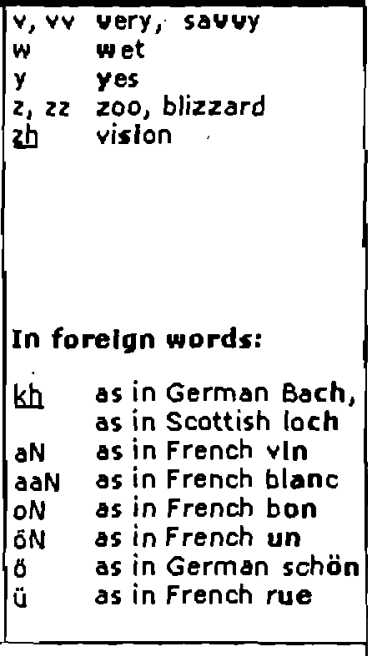

stress marks: "as in secret [se'ek rat]

- as in secretary [s ékr a tèree]

Nate: This diction ary uses double letters to show many sounds in the middle of words, because English spelling normally uses double letters in these positions. This is one of several ways that the system of spelling pronunciations here is more natural and easier to use than the systems in many other dictionaries.

Fig. 10

EWED's more conventional text-internal cross-references are also active. The explicit remote article-external cross-references are given in blue text and have an important role to play in maintaining the textual cohesion of this dictionary. A click on the explicit reference "See also genie" in the article of jinni will take the user directly to genie, where the cross-reference is met by a corresponding active cross-reference to complete the circle. This is unfortunately not always the case. The explicit cross-references to abalone at ear shell and sea ear are active, but their corresponding cross-references at abalone are not.

Explicit article-external cross-references that are complicated by polysemy are not treated adequately. In the case of the synonymous pair hemp and marijuana, for example, the use of cross-references is confusing. A cross-reference "See also marijuana" is listed under the correct sense of hemp, but it is not specified whether hemp can be used as a synonym for both senses of marijuana or, if not, for which sense it can act as a synonym. Once again the circle is not completed by a corresponding active cross-reference at the address of this cross-reference (i.e. marijuana). This creates even more confusion in the user's mind and compounds the error made by the compilers.

Deliberately monodirectional explicit article-external cross-references are also employed in EWED, with more success. They are particularly effective 
when used in the etymology article position. In the case of genie, for example, the etymology is related to the Latin "genius". Instead of repeating the full etymology of "genius", the user can click on the cross-reference "(see genius)" and be transported to the article for genius in which the full etymology is explained.

Not all the article-external cross-references are explicit though. Probably the most innovative mediostructural elements are the implicit cross-references. A double-click on any word in the microstructure, will prompt a small screen called "Quickdefine" to appear. One can, for example, highlight "panama hats" in the the microstructure of jipijapa and double click with the result as shown in Fig. 11.

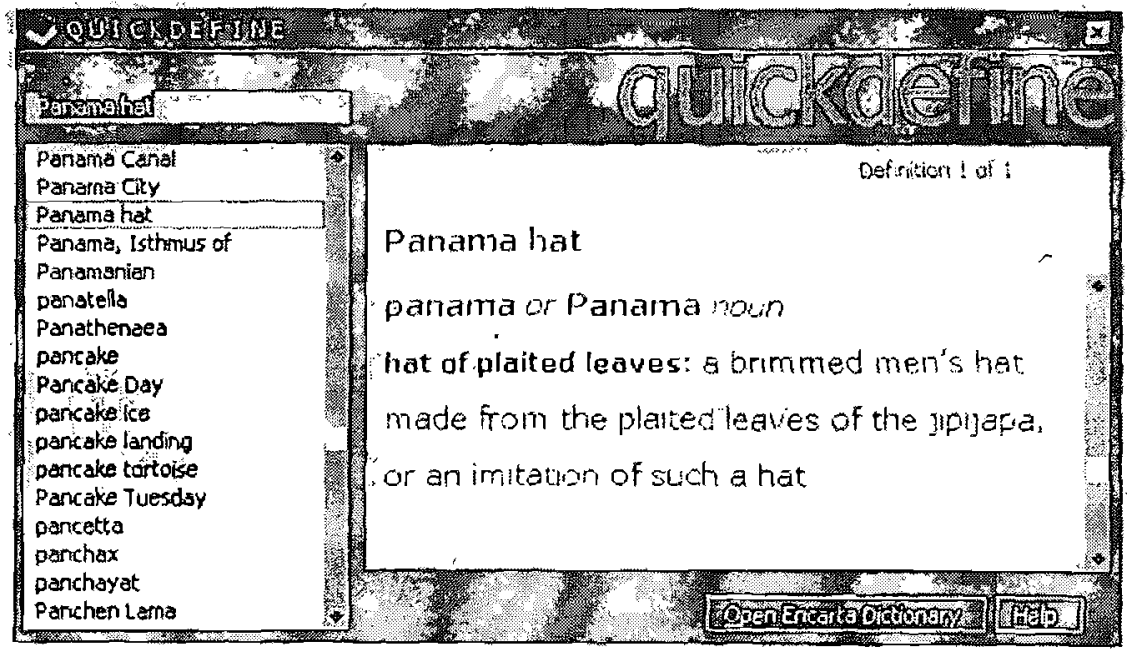

Fig. 11

This is yet another user-friendly feature of EWED that gives the user rapid access to the information he/she desires. EWED goes one step further by allowing users to obtain a "quickdefine"-window for search terms in ordinary Windows-based word processors such as Microsoft Word by highlighting the term and then clicking on the quickdefine desktop item, rather than opening the whole dictionary. The emphasis in both these procedures is on fast, effective access to the desired information.

\section{$3.2 \quad$ ELHAT}

ELHAT's mediostructure has unfortunately not even remotely reached the standards of innovation set by EWED, as is to be expected in such a far more modest attempt. The mediostructure is restricted to explicit article-external cross-references. These are generally well implemented and in the case of cross- 
references to polysemous articles, the sense to which the cross-reference applies is mentioned, e.g. "Vgl. KAALVUIS, 2" at kaalkop. This level of accuracy is what was needed in EWED.

ELHAT fails in another important aspect though, by not consistently completing the bidirectionality of active cross-references. At kaalvuis the cross-reference is met by the entry "kaalkop (b.nw. en bw. bet. 4)", but in this case the cross-reference is passive. Cross-references such as this one should also be active so that the dictionary can be the cohesive entity it has the potential to be.

\section{Conclusion}

Both the dictionaries under discussion have similar target user groups, with the primary difference being the language spoken by each group. The compilers of each of these dictionaries should take note of the innovative procedures followed by the compilers of the other. In order to keep these products viable at a time when CD-ROM dictionaries are increasingly under threat of being rendered obsolete by counterparts on the Internet, lexicographers need to make full use of the superior searchability provided by the CD-ROM format at the moment. In this regard the guide structures, and in particular the access and mediostructures, have an important role to play. A cross-pollination of features between CD-ROM dictionaries will improve the accessibility of the dictionaries and ultimately benefit their target users.

\section{Bibliography}

\section{Dictionaries}

Elektroniese Verklarende Handwoordeboek van die Afrikaanse Taal. 2.00.2000. Perskor. Microsoft Encarta World English Dictionary. 1999. Microsoft Corporation

\section{Other Sources}

Gouws, R.H. and D.J. Prinsloo. 1998. Cross-Referencing as a Lexicographic Device. Lexikos 8: 1736.

Hausmann, F.J., et al. (Eds.). 1989-1991. Wörterbücher. Ein internationales Handbuch zur Lexikographie Dictionaries/An International Encyclopedia of Lexicography/Dictionnaires. Encyclopédie internationale de lexicographie. Berlin: Walter de Gruyter.

Hausmann, F.J. and H.E. Wiegand. 1989. Component Parts and Structures of Monolingual Dictionaries. Hausmann, F.J. et al. (Eds.). 1989-1991: 328-360.

Louw, P.A. 1999. Access Structures in a Standard Translation Dictionary. Lexikos 9: 108-118.

Louw, P.A. 1999a. Portals to Knowledge: CD-ROM Encyclopaedias, with Specific Reference to Microsoft Encarta 99 Encyclopedia. Lexikos 9: 283-293.

Louw, P.A. and R.H. Gouws. 1996. Lemmatiese en rielemmatiese adressering in Afrikaanse vertalende woordeboeke. South African Journal of Linguistics 14(3): 92-100. 